\title{
In vitro rumen fermentation kinetics of diets containing oldman saltbush hay and forage cactus, using a cattle inoculum
}

\author{
[Cinética de fermentação ruminal in vitro de dietas contendo feno de erva-sal e palma \\ forrageira, utilizando inóculo bovino] \\ M.S.L. Tosto ${ }^{1}$, G.G.L. Araújo $^{2}$, L.G.P. Ribeiro ${ }^{3}$, L.T. Henriques ${ }^{4}$, D.R. Menezes ${ }^{5}$, \\ A.M. Barbosa ${ }^{1}$, C.O. Romão \\ ${ }^{1}$ Universidade Federal da Bahia - UFBA - Salvador, BA \\ ${ }^{2}$ Embrapa Semiárido - Petrolina, PE \\ ${ }^{3}$ Embrapa - Juiz de Fora, MG \\ ${ }^{4}$ Universidade Federal da Paraíba - CCA/UFPB - Areia, PB \\ ${ }^{5}$ Universidade Federal do Vale do São Francisco - CCA/UNIVASF - Petrolina, PE
}

\begin{abstract}
The aim of this experiment was to evaluate, by means of the semi-automated in vitro gas production technique, fermentation kinetics of carbohydrates and degradability of dry matter (DM) and organic matter (OM) of diets containing oldman saltbush hay levels $(8.4 ; 18.8 ; 31.2$ and $48.3 \%)$ associated to forage cactus in natura. Pressure readings of the gases were done with a pressure transducer at 2, 4, 6, 8, 10, 12, 17, 20, 24, 28, 34, 48, 72 and $96 \mathrm{~h}$ post-inoculation. The rumen kinetics was described by the following parameters: maximum potential of gas production, lag time and production rates of gas (k), fibrous carbohydrates (FC) and nonfibrous carbohydrates (NFC). It could be observed that the addition of oldman saltbush hay to the diets promoted a quadratic effect in the production of gases originated from NFC. However, there was no significant effect on the production of gases originated from FC and on production rates of gases from NFC and FC. The degradability of DM and OM did not differ due to the addition of oldman saltbush hay. The use of $8.4 \%$ hay and $74.9 \%$ forage cactus promoted the maximum potential of production of gases from the fibrous fraction of diets containing cactus and oldman saltbush hay.
\end{abstract}

Keywords: Atriplex nummularia, degradability, forages, Opuntia ficus indica

\section{RESUMO}

O objetivo deste experimento foi avaliar, por meio da técnica in vitro semiautomática de produção de gases, a cinética de fermentação dos carboidratos e a degradabilidade da matéria seca (MS) e da orgânica (MO) de dietas contendo níveis de feno de erva-sal (8,4; 18,8; 31,2 e 48,3\%) associado à palma forrageira in natura. As leituras de pressão dos gases foram feitas com transdutor de pressão às 2, 4, 6, 8, 10, 12, 14, 17, 20, 24, 28, 34, 48, 72, 96 horas pós-inoculação. A cinética ruminal foi descrita pelos parâmetros: potencial máximo de produção de gases, "lag time" e taxa de produção de gases ( $k$ ) dos carboidratos fibrosos (CF) e não fibrosos $(C N F)$. Verificou-se que a adição de feno de erva-sal às dietas promoveu efeito quadrático na produção de gases provenientes dos CNF, em que o menor valor observado $(136,48 \mathrm{~mL})$ foi encontrado com a adição de $38,25 \%$ de feno, e o maior valor, com a adição de $8,4 \%$ de feno e 74,9\% de palma forrageira. $O$ tempo de latência teve comportamento quadrático em função da adição de feno. No entanto não houve efeito significativo na produção de gases provenientes dos CF (média de 111,6mL) e nas taxas de produção de gases

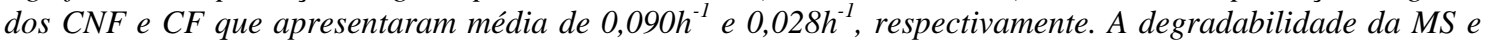
MO não diferiram em função da adição de feno de erva-sal e apresentaram médias de 85,8 e 90,9\%, respectivamente. $O$ uso de $8,4 \%$ de feno e 74,9 de palma forrageira propiciou o máximo potencial de produção de gases da fração fibrosa de dietas contendo palma e feno de erva-sal.

Palavras-chave: Atriplex nummularia, degradabilidade, forragens, Opuntia ficus indica

Recebido em 11 de junho de 2013

Aceito em 30 de julho de 2014

E-mail: mtosto@ufba.br 


\section{INTRODUCTION}

Halophyte plants are forage sources that are commonly utilized in many parts of the world. Among these plants, oldman saltbush (Atriplex nummularia) has been used to sustain livestock activities in regions where animal feed is scarce.

Oldman saltbush is tolerant to salinity and has the capacity to accumulate significant levels of salts within its tissues, allowing it to adapt to arid and semi-arid regions where the average annual rainfall ranges from 200 to $400 \mathrm{~mm}$ (Le Houérou, 1993). In these regions, the production of dry matter from fresh material is approximately 3.4ton/ha/year during low-rainfall conditions (390 mm/year) and 8.0ton/ha/year when irrigated (El Shaer, 2010).

Several studies have previously evaluated the nutritional quality of oldman saltbush and its usage in the feeding of small ruminants, particularly sheep. El-Waziry (2007) reported that despite the satisfactory crude protein content detected within its leaves, $126-144.5 \mathrm{~g} \cdot \mathrm{kg}^{-1}$ in dry matter (DM), Atriplex nummularia is only moderately digestible, exhibiting low digestibility of ether extracts and containing high levels of oxalate and minerals and low levels of soluble carbohydrates. In addition, the fresh leaves of this forage source contain high levels of lignin $\left(85 \mathrm{~g} \cdot \mathrm{kg}^{-1}\right)$ in the DM (El-Waziry, 2007). Thus, the identification of a forage source that could be combined with oldman saltbush to diminish its negative characteristics is urgently needed.

The forage cactus (Opuntia fícus indica) is a member of the cactaceae that is adapted to semiarid regions and that contains low levels of dry matter, crude protein and fiber, and high levels of soluble carbohydrates. The advantages of utilizing cactus as a forage source in conjunction with oldman saltbush have been described by Ben Salem et al. (2002), who reported the possibility of minimizing the negative effects of using oldman saltbush as an exclusive feed by combining it with forage cactus. However, few specific studies have evaluated the positive effects that such a combination confers in terms of rumen fermentation kinetics.

The semi-automated in vitro gas production technique has been successfully utilized in this type of study. Apart from the characterization of rumen kinetics, the gas production technique enables the study of anti-nutritional factors present in the feedstuffs. In contrast with in situ or in vitro techniques based on gravimetric determinations, the gas production technique does not allow for the solubilization of the antinutritional factors; thus, there is no risk of their being quantified as degraded dry matter. Even though the volume of gas produced when feeds are incubated in vitro with buffered rumen fluid is only a reflection of rumen events, it has been related to whole tract digestibility and has also been used as a means of estimating the metabolisable and net energy content of feeds (Rymer and Givens, 2002); then, the vitro gas production could be used as a tool to evaluate nutritive value and compare different forage sources as a preliminary study before the realization of field animal trial.

In this context, this study aimed to evaluate the range and kinetics of the rumen fermentation of diets containing oldman saltbush hay combined with forage cactus by means of the semiautomated in vitro gas production technique.

\section{MATERIALS AND METHODS}

The study was conducted at Semiarid Embrapa, located in Petrolina-PE, Brazil.

The treatments evaluated corresponded to diets containing 8.4, 18.8, 31.2, and $48.3 \%$ oldman saltbush (Atriplex nummularia) hay (\% in DM) in combination with forage cactus (Opuntia fícus-indica Mill) (Table 1). Concentrates containing different levels of urea: ammonium sulfate (9:1), ground corn and soybean meal were included to ensure that all diets contained equal amounts of protein and energy.

Oldman saltbush was obtained from growing areas in Semiarid Embrapa. The material collected was weighed, dried in the sun and then chopped. Forage cactus were obtained from the experimental field of Semiarid Embrapa and then processed in a stationary chopper that was appropriate for forage cactus. Before the formulation of the complete diets, the concentrate ingredients were pre-mixed (Table 1) and then added to the oldman saltbush and cactus in pre-established amounts. Samples of the diet mixes and feeds were collected, dried in a ventilation oven at $55^{\circ} \mathrm{C}$ for 72 hours, ground in a Willey mill with a $1 \mathrm{~mm}$ sieve, and collected in polyethylene vials for further laboratory analyses. 
In vitro rumen fermentation...

Table 1. Diets ingredients, expressed in $\mathrm{g} \cdot \mathrm{kg}^{-1}$ dry matter (DM)

\begin{tabular}{lcccc} 
& \multicolumn{3}{l}{ Oldman saltbush hay levels $(\%$ on DM) } & \\
\cline { 2 - 4 } & 8.4 & 18.8 & 31.2 & 48.3 \\
\hline Ingredients $\left(g . \mathrm{kg}^{-1}\right.$ of dry matter $)$ & & & & \\
Old man saltbush hay & 84 & 188 & 312 & 483 \\
Spineless cactos & 749 & 576 & 370 & 72 \\
Concentrate & 167 & 236 & 318 & 445 \\
R:C ratio & $83.3: 16.7$ & $76.4: 23.6$ & $68.2: 31.8$ & $55.5: 44.5$ \\
& & & & \\
Chemical composition of the diets $\left({. \mathrm{kg}^{-1}}^{-1}\right.$ of dry matter) & & & \\
Dry matter (\%) & 33,9 & 47,3 & 63,0 & 85,7 \\
Organic matter & 886 & 884 & 883 & 880 \\
Mineral matter & 114 & 116 & 117 & 120 \\
Crude protein & 125 & 137 & 135 & 138 \\
Neutral detergent fiber & 239 & 252 & 272 & 307 \\
Acid detergent fiber & 161 & 170 & 183 & 193 \\
Lignin & 39 & 46 & 53 & 63 \\
Cellulose & 122 & 124 & 130 & 130 \\
Hemicellulose & 78 & 82 & 89 & 114 \\
Total carbohydrates & 746 & 731 & 735 & 728 \\
Non-fibrous carbohydrates & 507 & 479 & 463 & 421 \\
Ether extract & 16 & 16 & 15 & 14 \\
TDN & 743 & 737 & 667 & 680 \\
ME (kcal/kg of DM) & 2687 & 2663 & 2411 & 2458 \\
\hline
\end{tabular}

R:C - roughage:concentrate; *ADIN - Acid detergent insoluble nitrogen; **NDIN - Neutral detergent insoluble nitrogen; NDFp - neutral detergent fiber corrected for protein; ADFp - acid detergent fiber corrected for protein.

Analyses of the dry matter (DM), crude protein (CP) and mineral matter (MM) of the feeds (Table 2) and diets (Table 1) were performed in the Laboratories of Animal Nutrition of Semiarid
Embrapa, according to methodologies no. 7.007, 7.015 and 7.009 as described by the AOAC (Official..., 1984).

Table 2. Chemical composition of feeds, expressed in g. $\mathrm{kg}^{-1}$ dry matter (DM)

\begin{tabular}{lcccccc}
\hline \multirow{2}{*}{ Variables } & Forage & Oldman & \multicolumn{4}{c}{ Concentrates of the treatments } \\
\cline { 5 - 7 } & cactus & saltbush & 8.4 & 18.8 & 31.2 & 48.3 \\
\hline Dry matter (\%) & 14.6 & 91.4 & 91.5 & 92.0 & 91.4 & 91.0 \\
Organic matter & 882 & 847 & 924 & 919 & 919 & 916 \\
Mineral matter & 118 & 153 & 76 & 81 & 81 & 84 \\
Crude protein & 45 & 88 & 498 & 402 & 286 & 208 \\
ADIN* & 1 & 2 & 5 & 4 & 6 & 3 \\
NDIN** & 5 & 4 & 11 & 11 & 16 & 8 \\
NDFp & 238 & 516 & 104 & 75 & 73 & 91 \\
ADFp & 170 & 346 & 30 & 32 & 38 & 30 \\
Lignin & 37 & 114 & 11 & 13 & 13 & 11 \\
Cellulose & 133 & 232 & 19 & 19 & 25 & 19 \\
Hemicellulose & 68 & 170 & 74 & 43 & 35 & 61 \\
Ether extract & 17 & 10 & 13 & 16 & 16 & 18 \\
Total carbohydrates & 819 & 749 & 416 & 499 & 624 & 690 \\
Non-fibrous carbohydrates & 581 & 233 & 312 & 424 & 551 & 599 \\
\hline
\end{tabular}

*ADIN - Acid detergent insoluble nitrogen; **NDIN - Neutral detergent insoluble nitrogen; NDFp - neutral detergent fiber corrected for protein; ADFp - acid detergent fiber corrected for protein. 
The contents of total carbohydrates (TCHO) were calculated using the equations described previously by Sniffen et al. (1992). Concentrations of neutral detergent fiber (NDF, with the addition of thermostable amylase), acid detergent fiber (ADF, determined sequentially due to the presence of soluble carbohydrates) and lignin (LIG, in $72 \%$ sulfuric acid) were determined according to methods described previously by Van Soest et al. (1991), with further correction for the protein present in NDF and $\mathrm{ADF}$, and the levels of non-fibrous carbohydrates (NFC), cellulose (CEL) and hemicelluloses (HEM) were estimated using those authors equations described previously. The neutral detergent-insoluble nitrogen (NDIN) and acid detergent-insoluble nitrogen (ADIN) contents were assessed using techniques described previously by Licitra et al. (1996).

For the energetic values of the diets, the data obtained from an experiment assessing apparent digestibility were applied to the following equation: $\mathrm{TDN}(\%)=\mathrm{DNFC}+\mathrm{DCP}+(\mathrm{DEE} \times$ 2.25) + DNDF, in which " $\mathrm{D}$ " corresponds to the apparent digestibility of each referenced component (National..., 2001). The metabolizable energy was determined as described in a report by Harris (1970), which assumed that $\mathrm{TDN}=4.409 \times \mathrm{DE}$ (digestible energy) and metabolizable energy $(\mathrm{ME})=0.82 \times$ DE.

The evaluation of the rumen fermentation kinetics of the diets and feeds was performed by the semi-automated in vitro gas production technique described previously by Maurício et al. (2003) at the laboratory of gas production of Semiarid Embrapa.

The feeds containing varying proportions of oldman saltbush were weighed separately and then were mixed. One gram of each mixed-feed diet was added into individual fermentation vials
$(160 \mathrm{~mL})$ that were previously injected with $\mathrm{CO}_{2}$.

The ruminal fluid used as inoculum was obtained individually from three adult castrated male Sindi cattle via ruminal cannula. The animals were maintained for three days prior to collection on a diet consisting of oldman saltbush and forage cactus ad libitum, without defined proportions, plus $1 \mathrm{~kg}$.day ${ }^{-1}$ of feed concentrate.

The ruminal fluid of each animal was filtered separately through a nylon sieve and maintained under continuous injection of $\mathrm{CO}_{2}$ in thermal bottles that were previously heated to $39^{\circ} \mathrm{C}$. Three vials were utilized per sample for the fluid from each of the animals (totaling 9 samples per diet or feed assessed). Ten milliliters of ruminal fluid were inoculated in each of these vials, which were then sealed with rubber corks (14 $\mathrm{mm}$ ), placed in a polystyrene container, manually shaken (every hour), and kept in a temperaturecontrolled room at $39^{\circ} \mathrm{C}$.

Vials containing only ruminal fluid and culture medium (buffer) were used as blanks.

The pressure originating from the gases that accumulated within the upper part of the vials was measured using a pressure transducer (PressDATA 800) connected to a needle (0.6 $\mathrm{mm})$. Readings were taken at 2, 4, 6, 8, 10, 12, 14, 17, 20, 24, 28, 34, 48, 72, and $96 \mathrm{~h}$. The pressure data ( $\mathrm{P}$ in psi - pressure per square inch) were converted into measurements of gas volume (V) by applying the quadratic equation: $\mathrm{V}=$ $0.17454 \mathrm{P}^{2}$ (s.e. 0.0916) + 4.09089 P (s.e. $0.0637)+0.00315$ (s.e. 0.003$), \mathrm{R}^{2}=0.99$.

The data from the cumulative production of the gases were analyzed by the two-compartmental model described previously by Schofield et al. (1994):

$$
V(t)=\frac{V f 1}{\left[1+e^{(2-4 m 1(\operatorname{Lag}-T))}\right]}+\frac{V f 2}{\left[1+e^{(2-4 m 2(\operatorname{Lag}-T))}\right]}
$$

In this equation, $V(t)$ represents the total maximal volume of gases produced; $V f 1$ represents the maximal volume of gas for the rapidly digested fraction (NFC); $V f 2$ represents the maximal volume of gas for the slowly digested fraction (FC); $m 1$ stands for the specific growth rate for the rapidly degraded fraction; $m 2$ stands for the specific growth rate for the slowly degraded fraction; Lag represents the duration of the initial events of digestion (lag period), which is present in the two phases; and $\mathrm{T}$ stands for the time of fermentation. 
The fermentation residues were obtained by filtration of the contents of the fermentation vials through filter crucibles (porosity 1). These residues were dried at $105^{\circ} \mathrm{C}$ until a constant weight was reached, and the results were used for the calculations of in vitro DM degradability.

For the evaluation of degradation kinetics (gravimetric technique), the exponential decay model, corrected for the lag period, was applied as described previously by Snedecor \& Cochran (1989):

$$
Y=b^{\prime}-B * \exp \left(-c^{*} t\right)
$$

In this equation, $Y$ represents the residue of DM at time $t ; b$ ' represents the potential degradation of the DM fraction; $B$ represents the potentially degradable insoluble fraction, which will become degradable as a function of time at degradation rate $c$; $\exp$ represents the base of the natural logarithms; $c$ represents the degradation rate of fraction $B$ per time unit $\left(\mathrm{h}^{-1}\right)$; and $\mathrm{t}$ represents the incubation time. The Parameters of rumen fermentation range and kinetics of the feeds obtained are demonstrated in Table 3.

Table 3. Parameters of rumen fermentation range and kinetics of the feeds

\begin{tabular}{lcccccc}
\hline \multirow{2}{*}{ Variables } & \multirow{2}{*}{$\begin{array}{c}\text { Forage } \\
\text { cactus }\end{array}$} & \multirow{2}{*}{$\begin{array}{c}\text { Oldman } \\
\text { saltbush }\end{array}$} & 8.4 & 18.8 & 31.2 & 48.3 \\
\cline { 4 - 6 } vNFC $(\mathrm{mL})$ & 222.5 & 76.1 & 133 & 183.3 & 197.2 & 208.8 \\
$\mathrm{kNFC}\left(\mathrm{h}^{-1}\right)$ & 0.082 & 0.11 & 0.117 & 0.111 & 0.088 & 0.107 \\
$\mathrm{vFC}(\mathrm{mL})$ & 105.5 & 47.8 & 133.4 & 138.6 & 138.5 & 144.4 \\
$\mathrm{kFC}\left(\mathrm{h}^{-1}\right)$ & 0.022 & 0.036 & 0.033 & 0.028 & 0.025 & 0.023 \\
Lag $(\mathrm{h}: \mathrm{min})$ & $01 \mathrm{~h}: 38 \mathrm{~min}$ & $04 \mathrm{~h}: 15 \mathrm{~min}$ & $05 \mathrm{~h}: 03 \mathrm{~min}$ & $04 \mathrm{~h}: 54 \mathrm{~min}$ & $04 \mathrm{~h}: 03 \mathrm{~min}$ & $04 \mathrm{~h}: 59 \mathrm{~min}$ \\
\hline
\end{tabular}

vNFC - volume of gases from non-fibrous carbohydrates; kNFC - production rate of gases from non-fibrous carbohydrates; Lag - lag phase; vFC - volume of gases from fibrous carbohydrates; kFC production rate of gases from fibrous carbohydrates.

The data were subjected to variance analysis to determine the effects of different levels of oldman saltbush hay. Regression analysis was utilized for the significant effects $(\mathrm{P}<0.05)$ of the model using the software Sistema de Análises Estatísticas e Genéticas (Sistema..., 2007).

\section{RESULTS}

The addition of oldman saltbush to the diets resulted in a quadratic effect in the volume of gases that originated from the NFCs. The diet containing $8.4 \%$ oldman saltbush yielded greater gas production and, consequently, more fermentation (Table 4).

Table 4. Volume of gases from non-fibrous carbohydrates (vNFC), production rate of non-fibrous carbohydrates (kNFC), lag phase (Lag), volume of gases from fibrous carbohydrates (vFC) and production rate of gases from fibrous carbohydrates $(\mathrm{kFC})$ of experimental diets

\begin{tabular}{|c|c|c|c|c|c|c|c|c|}
\hline \multirow{2}{*}{ Parameters } & \multicolumn{4}{|c|}{ Oldman saltbush hay levels (\%) } & \multirow{2}{*}{$\mathrm{L}$} & \multirow{2}{*}{ Q } & \multirow{2}{*}{ Mean } & \multirow{2}{*}{$\mathrm{CV}$} \\
\hline & 8.4 & 18.8 & 31.2 & 48.3 & & & & \\
\hline vNFC $(\mathrm{mL})$ & 185.0 & 153.8 & 141.7 & 143.0 & 0.020 & $0.030^{1}$ & 155.9 & 12.64 \\
\hline $\operatorname{kNFC}\left(h^{-1}\right)$ & 0.092 & 0.096 & 0.090 & 0.081 & ns & Ns & 0.090 & 11.16 \\
\hline $\mathrm{vFC}(\mathrm{mL})$ & 111.7 & 113.3 & 107.4 & 114.0 & ns & Ns & 111.6 & 22.50 \\
\hline $\mathrm{kFC}\left(\mathrm{h}^{-1}\right)$ & 0.028 & 0.030 & 0.029 & 0.026 & ns & Ns & 0.028 & 15.92 \\
\hline Lag (h:min) & $1 \mathrm{~h}: 24 \mathrm{~min}$ & $1 \mathrm{~h}: 13 \mathrm{~min}$ & $1 \mathrm{~h}: 57 \mathrm{~min}$ & 3h:41min & 0.001 & $<0.0001^{2}$ & $2: 04$ & 17.76 \\
\hline
\end{tabular}


The gas production rates from the NFCs of the diets did not differ and exhibited an average of $0.090 \mathrm{~h}^{-1}$. The addition of oldman saltbush hay into the diets decreased the gas production, with the lowest gas volume of $136.48 \mathrm{~mL}$ resulting from the addition of $38.2 \%$ hay. The lag time varied quadratically; the shortest time resulted from the addition of $17.25 \%$ oldman saltbush hay into the diet, from which there was an increase during this period.

The volume and production rate of gases from the fibrous carbohydrates (FCs) were not affected by the levels of oldman saltbush hay added to the diets and exhibited average values of $111.6 \mathrm{~mL}$ and $0.28 \mathrm{~h}^{-1}$, respectively. The maximum potential of gas production was observed in the diet containing $8.4 \%$ oldman saltbush hay and $74.9 \%$ forage cactus, which yielded a gas volume of $296.7 \mathrm{~mL}$ produced due to degradation of the FC and NFC fractions (vFC + vNFC).

A significant decrease in gas production was observed in response to the altered levels of NFCs resulting from the addition of oldman saltbush hay to the diets. There was no significant difference in the potential degradation of DM and OM, which exhibited mean values of $85.8 \%$ and $90.9 \%$, respectively. However, the potentially degradable insoluble DM fractions exhibited quadratic behavior, which was proportional to the amounts of oldman saltbush hay added to the diets. The diet containing $8.4 \%$ exhibited the lowest percentage of the potentially degradable insoluble fraction (B) and the highest degradation rate of this fraction (Table 5).

Table 5. Means of the parameters of in vitro degradation kinetics of dry matter (DM) and organic matter $(\mathrm{OM})$, in function of oldman saltbush hay levels in the diets

\begin{tabular}{|c|c|c|c|c|c|c|c|c|}
\hline \multirow{2}{*}{ Parameters } & \multicolumn{4}{|c|}{ Oldman saltbush hay levels (\%) } & \multirow{2}{*}{$\mathrm{L}$} & \multirow{2}{*}{ Q } & \multirow{2}{*}{ Mean } & \multirow{2}{*}{$\mathrm{CV}$} \\
\hline & 8.4 & 18.8 & 31.2 & 48.3 & & & & \\
\hline $\mathrm{DM} \mathrm{b}(\%)$ & 86.2 & 85.9 & 87.0 & 83.9 & $\mathrm{~ns}$ & ns & 85.8 & 1.5 \\
\hline DM B (\%) & 65.4 & 74.6 & 75.5 & 80.3 & $*$ & $*^{1}$ & 73.9 & 6.9 \\
\hline $\mathrm{DM} K d\left(\mathrm{~h}^{-1}\right)$ & 0.07 & 0.06 & 0.06 & 0.06 & $*^{2}$ & ns & 0.06 & 9.1 \\
\hline $\mathrm{OM} \mathrm{b}(\%)$ & 91.6 & 91.1 & 92.6 & 88.4 & ns & ns & 90.9 & 2.0 \\
\hline OM B $(\%)$ & 71.1 & 79.5 & 79.1 & 81.9 & $*^{3}$ & ns & 77.9 & 6.2 \\
\hline OM Kd $\left(h^{-1}\right)$ & 0.09 & 0.09 & 0.08 & 0.08 & $*$ & $*^{4}$ & 0.08 & 8.2 \\
\hline
\end{tabular}

$\mathrm{b}$ - potential degradation; B - potentially degradable insoluble fraction; $\mathrm{Kd}$ - degradation rate of fraction $\mathrm{B} ;{ }^{1} \hat{\mathrm{Y}}=$ $57.059+10.028 \mathrm{x}-1.093 \mathrm{x}^{2}\left(\mathrm{R}^{2}=0.93\right) ;{ }^{2} \hat{\mathrm{Y}}=0.070-0.004 \mathrm{x}\left(\mathrm{R}^{2}=0.99\right) ;{ }^{3} \hat{\mathrm{Y}}=69.929+3.188 \mathrm{x}\left(\mathrm{R}^{2}=0.77\right) ;{ }^{4} \hat{\mathrm{Y}}=0.099-$ $0.0092 \mathrm{x}+0.00076 \mathrm{x}^{2}\left(\mathrm{R}^{2}=0.97\right) ;$ ns - not significant.

\section{DISCUSSION}

The forage sources in the first diet $(8.4 \%$ of oldman saltbush hay) were largely derived from forage cactus (74.9\%), and due to the composition of this cactus (high NFC content and reduced NDF and LIG content) and the gas production observed during its fermentation (Table 3), it is possible that these factors contributed to the greater volume of gases that was produced by this diet.

Oldman saltbush grass is rich in lignins (113 $\mathrm{g} . \mathrm{kg}^{-1}$ in DM), and the susceptibility of its different carbohydrates to bacterial degradation varies greatly according to their physicochemical properties or other factors that limit the access of bacterial enzymes to their substrates. Thus, the decreased gas production might directly reflect the increased proportions of oldman saltbush hay in the diets.

The addition of hay levels in excess of $38.2 \%$ promoted increases in the gas production from NFCs. This observation might be attributed to the fermentative characteristics of the concentrate, which was present at $44.5 \%$ in the diet with $48.3 \%$ hay, rather than to the levels of hay, which also contributed to the volume of gases produced by the NFCs $(208.8 \mathrm{~mL})$ of concentrate 4 (Table 3 ).

In contrast, Moreira et al. (2010) reported that increased gas production was associated with the silages of sorghum and corn. The sources of carbohydrates (flint corn, dent corn and citrus pulp) exhibited higher fermentation rates, which possibly result from the increased production of acetate from the fermentation of the FCs present 
in the silages effects that were contrary to those observed in this study.

Fermentation gases are produced predominantly when the substrates are fermented to acetate and butyrate; lower amounts of gases are associated with the reaction of propionate with the culture medium (indirect production). Soluble carbohydrates produce relatively higher amounts of propionate, whereas the inverse is observed with FCs (El-Waziry, 2007). However, because of the greater availability of rapidly fermentable carbohydrates, more gas is produced from the NFCs in feeds that contain this nutrient, a notion that is consistent with our findings.

The shorter lag time (Lag) observed might be attributed to the physicochemical characteristics of the forage cactus, which was present in significant amounts (576 g. $\mathrm{kg}^{-1}$ in DM) in the diet composed of $18.8 \%$ hay. The soluble fraction constitutes an energetic substrate of rapid fermentation that facilitates the adhesion and colonization of microorganisms, consequently elevating the fermentation of FC and reducing the Lag period. However, the importance of the soluble fraction starts to decrease when greater amounts of the components of the cell wall become dispensable (Noguera et al., 2005).

According to Detman et al. (2009), although the lag represented by the model of Schofield et al. (1994) results from mixed origins (i.e., common to the two digestion compartments), the fibrous fraction can be directly associated with most of the lag-related events, thereby accounting for the greater lag observed with feeds containing higher proportions of lignin. The diet composed of $48.3 \%$ oldman saltbush hay exhibited a greater Lag period ( 3 hours and 41 minutes). The longer Lag period observed in the diet with $48.3 \%$ hay might be attributed to the proportions of NDF (331 g. $\left.\mathrm{kg}^{-1} \mathrm{DM}\right)$ and LIG (63 g. $\left.\mathrm{kg}^{-1} \mathrm{DM}\right)$ in this diet.

However, high fermentation potential might be related to the profile of volatile fatty acids produced. The forage cactus contains high levels of pectin (Batista et al., 2003), which contributes to a greater production of acetate. Lower gas production is observed when propionate is formed, due to the absence of $\mathrm{CO}_{2}$ production. However, when fermentation is directed toward the formation of acetate and butyrate, the $\mathrm{CO}_{2}$ is produced, consequently increasing the volume of gases. In such cases the fermentation of the forage cactus results in the production of gases derived from NFCs, due to the fermentative property of pectin. The greater levels of pectin in the cactus-containing diets are reflected in the rate of gas production derived from NFCs (Figure 1).

The cumulative gas production and the contributions of the NFC and FC fractions in the four diets evaluated suggest that the fibrous fraction is more extensively degraded in the diet containing $8.4 \%$ hay (Figure 1), possibly due to the carbohydrate profile (i.e., pectin content) present in the cactus that renders it more easily degraded by the ruminal microorganisms. According to Van Soest (1994), the faster degradation of pectin for insoluble fibrous compounds results in greater production of acetate and fermentation gases.

These results might be associated with the roughage:concentrate ratio of the diets. Higher proportions of concentrate increase the availability of protein and carbohydrates in a synchronous manner, which might alter the acetate:propionate ratios, leading to greater efficiency of microbial degradation and usage of dietary N. Thus, although lower production of gases (from NFC and FC) was observed, the efficiency of diets with greater content of oldman saltbush was higher.

Lower production of gases attributed to increased FC and LIG content has been reported previously. Pereira et al. (2005) evaluated sunflower silages and observed reduced gas production from the more mature silages and silages with higher FC content. According to Jung and Allen (1995), the diversity of cell wall constituents is associated with variation in the digestibility of nutrients, which can be intrinsically linked to morphogenetic characteristics of the plants. Lignin is a phenyl propanol polymer that is found in the cell wall, and according to these authors, lignin composition and concentration might affect the rate and extent of fiber digestion. 

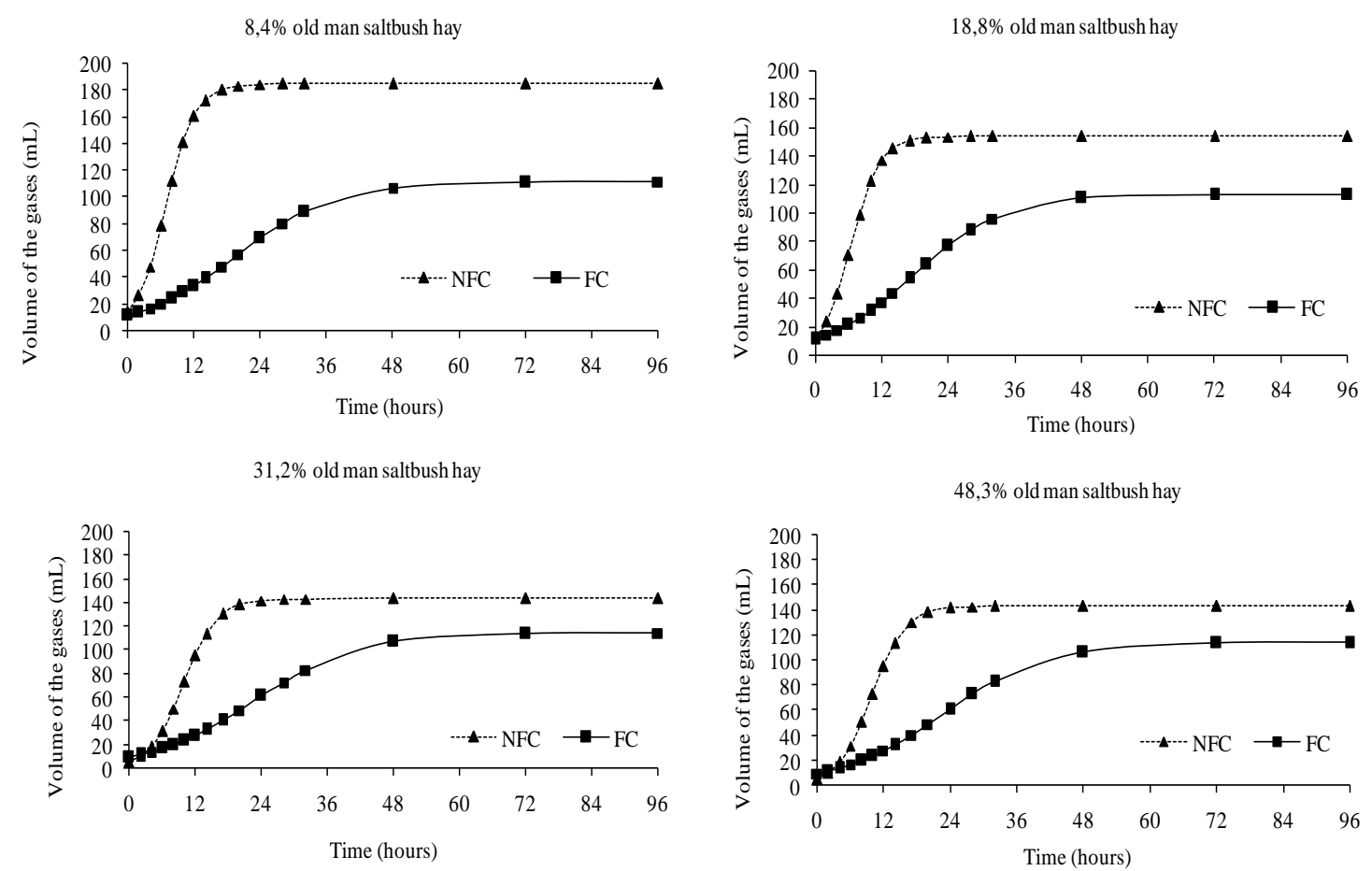

Figure 1. Gas production from the non-fibrous carbohydrates (NFC) and fibrous-carbohydrates (FC), due to oldman saltbush hay levels in the diets.

The possible low $\mathrm{pH}$ due to the elevated levels of NFCs in this diet might reduce the degradationresistant insoluble fraction (B). The insoluble DM fraction is associated with the fibrous fraction; thus, one can infer that the lower B in this diet is attributed to the following two effects related to the presence of NFC:pH effect and concentrate:carbohydrate effect (Mould et al., 1983). Soluble carbohydrates and starch can block the digestion of cellulose by reducing ruminal $\mathrm{pH}$ by promoting competition between cellulolytic and amylolytic bacteria for essential nutrients that are distinct in energy content, or by promoting the usage of alternative energy sources by certain cellulolytic bacteria.

Gonçalves et al. (2001) compared the degradation kinetics of roughages utilized in the feeding of dairy goats when the roughages were subjected to different $\mathrm{pH}$ levels. The authors observed a decrease in the degradability of DM and NDF at lower $\mathrm{pH}$ values. Likewise, Costa et al. (2009) evaluated the in vitro degradation of elephant grass supplemented with different sources of carbohydrate and proteins, demonstrating a decrease in the degradation rate of NDF that was attributed to increased amounts of soluble carbohydrates. Costa et al. (2008) also found a decrease in the degradation of fiber from low-quality tropical forages that were supplemented with starch. However, the addition of pectin did not impair the degradation of potentially degradable NDF. The authors attributed these results (lower degradation of fiber and DM) to the competition for nutrients between the ruminal microorganisms, which preferentially utilize soluble carbohydrates rather than FCs as energy sources.

Thus, the increased degradation rates of the fraction of DM and OM (Table 6) exhibited by the diet with $8.4 \%$ hay and $74.9 \%$ cactus were possibly attributed to the availability of carbohydrates that supplied the energy to increase the proliferation of the ruminal microorganisms.

The increased potentially soluble fraction of DM and $\mathrm{OM}$ and reduced degradation rates of this fraction (Table 5) due to the addition of hay in the diets can be associated with the physicochemical characteristics of the hay, which has an elevated lignin content (113 g. $\mathrm{kg}^{-1}$ DM). 


\section{CONCLUSIONS}

The addition of $8.4 \%$ hay in the diets resulted in the maximal gas production from the fibrous fraction of diets containing cactus and oldman saltbush hay. The combination of oldman saltbush hay with forage cactus represents an option for the roughage supplementation of cattlefeeds in semi-arid regions.

\section{REFERENCES}

BATISTA, A.M.; MUSTAFA, A.F.; MCALLISTER, T. et al. Effects of variety on chemical composition, in situ nutrient disappearance and in vitro gas production of spineless cactus. J. Sci. Food Agric., v.83, p.440$445,2003$.

BEN SALEM, H.; NEFZAOUI, A.; BEN SALEM, L. Supplementation of Acacia cyanophylla Lindl. Foliage-based diets with barley or shrubs from arid areas (Opuntia ficus-indica $f$. inermis and Atriplex nummularia L.) on growth and digestidility in lambs. Anim. Feed Sci. Technol., v.96, p.15-30, 2002

COSTA, V.A.C.; DETMAN, E.; VALADARES FILHO, S.C. et al. Degradação in vitro da fibra em detergente neutro de forragem tropical de alta qualidade em função da suplementação com proteína e/ou carboidratos. Rev. Bras. Zootec., v.38, p.1803$1811,2009$.

COSTA, V.A.C.; DETMANN, E.; VALADARES FILHO, S.C. et al. Degradação in vitro da fibra em detergente neutro de forragem tropical de baixa qualidade em função de suplementação com proteína e/ou carboidratos. Rev. Bras. Zootec., v.37, p.494-503, 2008.

DETMAN, E.; SILVA, J.F.C.; VÁSQUEZ, H.M. et al. Cinética da degradação ruminal dos carboidratos de quatro gramíneas em diferentes idades de corte e adubação nitrogenada: Técnica de produção de gases. Rev. Bras. Zootec., v.38, p.149-158, 2009.

EL SHAER, H.M. Halophytes and salt-tolerant plants as potential forage for ruminants in the Near East region. Small Rumin. Res., v.91, p.4-12, 2010.

EL-WAZIRY, A.M. Nutritive Value Assessment of Ensiling or Mixing Acacia and Atriplex Using In Vitro Gas Production Technique. Res. J. Agri. Biolog. Sci., v.3, p.605-614, 2007.

GONÇALVES, A.L.; LANA, R.P.; RODRIGUES, M.P. et al. Cinética de degradação de alguns volumosos usados na alimentação de cabras leiteiras por intermédio da técnica de produção de gases sob diferentes níveis de pH. Rev. Bras. Zootec., v.30, p.1904-1912, 2001.
HARRIS, L.F. Nutrition research technique for domestic and wild animal. v.1. Utah: Logan. (discontinuous pagination), 1970.

JUNG, H.G.; ALLEN, M.S. Characteristics of plant cell walls affecting intake and digestibility of forages by ruminants. J. Anim. Sci., v.73, p.2774-2790, 1995.

LE HOUÉROU, H.N. Salt tolerant plants for the arid regions of the Mediterranean isoclimatic zone. In: LEITH, H.; EL-MASOOM, A. (Eds.), Towards the rational use of high salinity - Tolerant Plants. Kluwer Academic Publications, Dordrecht, The Netherlands, 1993. p.405-411.

LICITRA, G.; HERNANDEZ, T.M.; VAN SOEST, P.J. Standardization of procedures for nitrogen fractionation of ruminant feeds. Anim. Feed Sci. Technol., v.57, p.347-358, 1996.

MAURÍCIO, R.M.; PEREIRA, L.G.R.; GONÇALVES, L.C.; RODRIGUEZ, N.M. Relação entre pressão e volume para implantação da técnica in vitro semi-automática de produção de gases na avaliação de forrageiras tropicais. Arq. Bras. Medic. Veter. Zootec., v.55, p.1013-1020, 2003.

MOREIRA, P.C.; REIS, R.B.; REZENDE, P.L.P. et al. Produção cumulativa de gases e parâmetros de France avaliados pela técnica semiautomática in vitro de fontes de carboidratos de ruminantes. Rev. Bras. Saúde Prod. Anim., v.11, p.452-462, 2010.

MOULD, F.L.; ØRSKOV, E.R.; MANNS, O. Associative effects of mixed feeds. I. Effects of type and level of supplementation and the influence of the rumen $\mathrm{pH}$ on cellulolysis in vivo and dry matter digestion of various roughages. Anim. Feed Sci. Technol., v.10, p.15-30, 1983.

NATIONAL Research Council - NRC. Nutrient Requirements of Dairy Cattle. 7.ed. Washington: National Academy Press. 2001.

NOGUERA, R.R.; SALIBA, E.O.; GONÇALVES, L.C., MAURÍCIO, R.M. Utilização da técnica de produção de gás para determinar a cinética de fermentação dos carboidratos estruturais e não estruturais em sorgo para forragem. Livest. Res. Rural Develop., v.17, p.5, 2005.

OFFICIAL Methods of Analysis - AOAC. Association of Official Analytical Chemists, Arlington, VA, USA, 1984.

PEREIRA, L.G.R.; MAURÍCIO, R.M.; GONÇALVES, L.C. et al. Avaliação da silagem de girassol (híbrido M734) obtidas em diferentes épocas de ensilagem pela técnica in vitro semi-automática de produção de gases. Braz. J. Vet. Res. Anim. Sci., v.42, p.273-283, 2005. 
RYMER, C. e GIVENS, D. Relationships between patterns of rumen fermentation measured in sheep and in situ degradability and the in vitro gas production profile of the diet. Anim. Feed Sci. Technol., v.101, p.31-44, 2002.

SISTEMA para Análises Estatísticas - SAEG, version 9.1. Viçosa: UFV. 2007.

SCHOFIELD, P.; PITT, R.E.; PELL, A.N. Kinects of fiber digestion from in vitro gas production. J. Anim. Sci., v.72, p.2980-2991, 1994.

SNEDECOR, G.W.; COCHRAN, W.G. Statistical Methods. 6.ed. Ames: The Iowa State University Press, 1989. 593p.
SNIFFEN, C.J.; OCONNOR, J.D.; VAN SOEST, P.J. A net carboydrate and protein sistem for evaluating cattle diets: II. Carboydrate and protein availability. $J$. Anim. Sci., v.70, p.3562-3577, 1992.

VAN SOEST, P.J. Nutritional ecology of the ruminant. 2.ed. Ithaca: Cornell University Press, 1994. 476p.

VAN SOEST, P.J.; ROBERTSON, J.B.; LEWIS, B.A. Methods fordietary fiber, neutral detergent fiber, and nonstarch polysaccharides in relation to animal nutrition. J. Dairy Sci., v.74, p.3583-3597, 1991. 